\title{
Application of Porter's Five Forces to Improve Competitiveness: Case of Featured SMEs in Medan
}

\author{
Prihatin Lumbanraja $^{1}$, Ritha F Dalimunthe ${ }^{2}$ and Beby Kendida Hasibuan ${ }^{3}$ \\ $\left\{\right.$ prihatin@usu.ac.id $\left.{ }^{1}\right\}$ \\ ${ }^{1,2,3}$ Faculty of Economic and Business, Universitas Sumatera Utara, Medan, Indonesia
}

\begin{abstract}
The role of micro, small and medium enterprises is always important to support the country's economic growth. As the market emerge and become larger, the competition within these enterprises has also risen to a new stage. One of the key to formulate strategies to improve the enterprises' competitiveness is through industrial analysis based on Porter's Five Force Model. This study aimed to map the application of porter's five forces within SMEs in Medan. A number of 300 SMEs were participated in this research. This paper conclude that most part of five forces analysis were conducted unawarely which resulted almost no strategies generated from the analysis. There should be a party that play role to help SMEs formulating their strategies based on five forces model and improve their competitiveness as whole.
\end{abstract}

Keywords: Competitiveness, Five Forces, Enterprises, Strategy

\section{Introduction}

Indonesia and other ASEAN countries has agreed to enter the new era of trade, Free Trade Agreement (FTA) between ASEAN countries. It practically has been applied since the begining of 2016. FTA without a doubt increase the competition between organization which can now freely trade with another organization between countries. World economics forum (2016) conclude that Indonesia's competitiveness index went down from 34th to 37th in 2016. The situation also affecting Small and Medium Enterprises (SMEs) which lead to downgrade of their product both for quality and price.

Small and Medium Enterprises (SMEs) played the most important role to support economic development in almost all countries as they gave the major contribution for economic development (Anggadwita and Mustafid, 2014). According to Indonesia Statistics Bureau (2015), SMEs contributed for around 60\% of GDP and absorb more that $97 \%$ labour forces. Asian Productivity Organization (2015) stated that the most important role of SMEs is to act as main core in economic development and productivity. In line with the statistics bureau, SMEs was believed as the major contributor toward one's GDP. World Bank (2018) stated that one key to sustainable growth of economics was the growth of SMEs in one's country. The growth will remain stable as long as it supported by healthy SMEs development. Despite their importance to support economics growth, SMEs lack of managerial practice to help them to develop their competitiveness.

Porter's five forces model was developed to evaluate one's competitiveness between five forces that drive organizaition. Dess et al. (2005) stated that the global use of Porter's Five Forces Model involved a continuous process of environmental scanning and monitoring while obtaining the competitiveness of potential rival. While the model has beed challenged by Karagiannopoulos et al. (2005) which stated that it 
lack explanation toward the expansion of distance learning industries, the five forces model is still widely used in many practical explanation (Aosa, 2009; Monbiot, 2011). Okoreh (2010) studied five forces model in telephone industry and conclude that five forces was not redundant or irrelevant, but open to development and future research.

Jaradat et al. (2013) used five force analysis in food industry. He conclude that the forces has an important influence in developing strategies to increase the competitive advantage and competitiveness of companies in the food industry. Five force helped business to their process of strategic decision making. Managers should involved the five forces to improve their competitive strategies so that companies remain competitive and able to dominate the market in the future. Dalken (2014) also examined the suitability of using five forces in measuring current business competition. Dalken emphasized that the five forces are still very applicable but not flexible enough to consider the power of informational technologies. If these two things can coexist, then the implementation of the five forces in the formulation of the strategy will be become better.

Previous works stated that Porter's Five Forces is still relevant to be used to evaluate one's competitiveness (Dalken, 2014; Jaradat et al. 2013; Monbiot, 2011). While it is globally used and suggested by many academia, it lack of actual practice in SMEs case. This study aimed to evaluate the SMEs' acceptance and applience toward Porter's Five Forces in their business environment.

\section{Literature Review}

\subsection{SMEs in Medan}

The previous part of this paper stated that SMEs contribute for around $60 \%$ of GDP while absorbing for $97 \%$ of labour forces (BPS, 2015). While it remain true, many of SMEs, especially in Medan, had not been registered yet. They actually harder to observe and evaluate as they could easily enter and exit the market at will. There were none central registry existed for SMEs. However, Lubis et al. (2018) stated that the government in Medan classified the SMEs in six sectors that become their focus on developing the SMEs; namely Rattan, Batik, Leather, Culinary, Souvenir, and Embroidery. Our study focussed in this classification.

Jamil and Muhamed (2011) identified the firm based on the number of their employees. A firm with number of employees less than 50 workers classified as small enterprises; 50-199 classified as medium enterprises; 200 or more classified as large enterprises. SMEs in Medan were regulated based on UU No 8/2008 which describe what the SMEs is. The classification is based on total assets and annual revenue. It is hard to classified the SMEs based on their assets as they were almost have no record for their firm's assets, if not mixed with private assets. Thus, our classification in this study was based on their yearly income. Firm that generated less than IDR 300 Million yearly considered as Micro Enterprises; 300 Million to 2 and half Billion considered as Small Enterprises; 2 and half Billon to 50 Billion considered as Medium Enterprises (UU No 8/2008).

\subsection{Competitiveness}

The term of 'competitiveness' literally refer to the ability of a company (even a country) to offer and deliver the goods and/or services which met the quality and 
market expectations, at the competitive price levels and were able to compensate for the factors of production while producing and delivering goods or services. Lawrence (in The Concise Encyclopedia of Economics, 1993) argued that competitiveness was difficult to define and it was related and closely to the productivity of a company or country. Lawrence emphasized that there were at least three question that need to be answered to explain the competitiveness of a company or country,

1) How good is the company's performance compared to other similar companies?

2) How good is the company's performance in the scope of the market?

3) Has the company provided the best performance?

These questions led to competitiveness and were focused on the forces associated with the business competition environment. It was close to the concept of Porter's Five Forces. In this approach, the five forces analysis would provide an overview in building business competitiveness based on five aspects described in five forces. Hill and Jones (2007) explained the relationship between five forces and competitiveness in industry. The illustration of how the forces explained the low profitability in industry and viable entries to an industry can be described through five forces.

\subsection{Porter's Five Forces}

Competitive forces is defined by Porter (1985) as the pressure in which affected the business unit while delivering their performance. The pressure or forces divided into five groups which later bacome Porter's Five Forcers. The unit of analysis in developing strategies and increasing business competitiveness through the Porter's Five Forces approach are grouped into five groups of analysis (Porter, 2008), namely:

\subsubsection{Suppliers}

Supplier strength will be the source in the achieving competitive advantage of the business unit. The fluency of materials from suppliers, the quality of raw materials, as well as access with suppliers was some illustration which could give a big picture to measure the strength of business units based on aspects of supplier strength. This study mapped the SMEs' apporach with their suppliers. Indiasty et al. (2014) stated that a powerful supplier can squeeze enough profit from business, especially the rare one.

\subsubsection{Customers}

This study used the customer approach as one of the sources of competitive advantage of business units. Customers were the core of business activities. If the business unit were able to bagiain equally or higher than the customer, the business will be guaranteed to run smoothly. In the aspect of customer strength, the analysis unit needs to pay attention to aspects such as priority customers, satisfaction, and measurement of customer loyalty. Alkhafaji (2003) argued that the barigaining power of the cusomer can be a threat to business.

\subsubsection{Rivalry}

Business competition was the basis to construct and build a business competitiveness. In fact, competitiveness was also prepared to survive in the fierce competition. The study mapped this rivalry forces based on the identification of competitors, the direction of competition applied by business units, and orientation in facing business competition. The control and management of the strength of business 
competition and rivalry could be the key to improve one's competitiveness. Lahiri (2007) conclude that rivalry did not associate with any generic strategies to gain competitiveness, yet it directly affect competitiveness.

\subsubsection{Substitute goods}

Substitute goods are essentially the same as competitors, but with a different approach. The presence of substitute goods will reduce direct demand from the products offered. Therefore, it is important to pay attention to the strength of substitute goods in an effort to maintain business competitiveness. The mapping that would be done by identifying substitution products from the business, identifying the potential for substitute goods, and analyzing trends in the presence of substitute goods. Riley (2012) said that the key characteristics to identify substitute goods was through the identification of products or services that could perform the similar function to satisfy demand.

\subsubsection{New-entry}

The presence of new competitors will increase the level of competition in a market. Analysis of the strength of new competitors is a control in maintaining the competitiveness of the company's business. Analysis of new competitor strengths can be done by analyzing market demand, market growth trends, and barrier to entry analysis.

The Five forces from business competition would be used as the basis for this paper's mapping study while appliying Porter's Five Forces to SMEs in Medan City. The analytical approach used related to efforts to develop the competitiveness of our SMEs in the Asean Economic Community (AEC).

\section{Research Method}

\subsection{Research time}

The study was conducted in Medan from March to August 2018.

\subsection{Participant}

A non-random sampling technique and the use of stratified-convenience sample were employed in this study. As previously stated, there were no registry for SMEs in Medan which force the use of non-random sampling. A number fo 50 SMEs for each classified SMEs in Medan were participated in this study. A number of 300 SMEs in total were participated in this study, which implying the final sample size of 300 SMEs participated in this study. The subject for this study was the SMEs' owner

\subsection{Data collection method}

Self-administered questionnaires were employed during our research. The questionnaires were based on the literature review in which adopted to satisfy our needs and mindset of SMEs. The questionnaires included items that measured five forces, the buyers, suppliers, rivalry, new entry and substitute goods. Each items were measured using five-point Likert scales. The questionnaires were also collected the SMEs' basic knowledge about five forces while collecting their characteristics such as educational attainment, sex, and opinion toward five forces. The distrubuted questionnaires were identical and were merged into a single dataset for our study purpose. 


\subsection{Validity and reliability}

Our validity and reliability test were conducted with 30 SMEs' owner around Universitas Sumatera Utara. These sample were not used in the future research. The result showed in Table 1.

Table 1. Validity and Reliability Result

\begin{tabular}{|c|c|c|c|c|}
\hline $\begin{array}{c}\text { Variab } \\
\text { le }\end{array}$ & Items & $\begin{array}{c}\text { Pearson } \\
\text { Correlati } \\
\text { on }\end{array}$ & $\begin{array}{c}\text { Critical } \\
\text { Value }\end{array}$ & Alpha \\
\hline \multirow{15}{*}{$\begin{array}{l}\text { Porters } \\
\text { ' Five } \\
\text { Forces }\end{array}$} & $\begin{array}{c}\text { Supplier } \\
1\end{array}$ & 0,801 & 0,361 & \multirow[t]{3}{*}{0,894} \\
\hline & $\begin{array}{c}\text { Supplier } \\
2\end{array}$ & 0,722 & 0,361 & \\
\hline & $\begin{array}{c}\text { Supplier } \\
3\end{array}$ & 0,756 & 0,361 & \\
\hline & Buyer1 & 0,644 & 0,361 & \multirow[t]{3}{*}{0,742} \\
\hline & Buyer2 & 0,672 & 0,361 & \\
\hline & Buyer3 & 0,651 & 0,361 & \\
\hline & $\begin{array}{c}\text { Substitut } \\
\text { el }\end{array}$ & 0,888 & 0,361 & \multirow[t]{3}{*}{0,901} \\
\hline & $\begin{array}{c}\text { Substitut } \\
\text { e2 }\end{array}$ & 0,875 & 0,361 & \\
\hline & $\begin{array}{c}\text { Substitut } \\
\text { e3 }\end{array}$ & 0,804 & 0,361 & \\
\hline & Rivalry1 & 0,865 & 0,361 & \multirow[t]{3}{*}{0,925} \\
\hline & Rivalry2 & 0,851 & 0,361 & \\
\hline & Rivalry3 & 0,823 & 0,361 & \\
\hline & $\begin{array}{c}\text { Newentr } \\
\text { yl }\end{array}$ & 0,682 & 0,361 & \multirow[t]{3}{*}{0,752} \\
\hline & $\begin{array}{c}\text { Newentr } \\
\text { y2 }\end{array}$ & 0,812 & 0,361 & \\
\hline & $\begin{array}{c}\text { Newentr } \\
\text { y3 }\end{array}$ & 0,721 & 0,361 & \\
\hline
\end{tabular}

We used Pearson's correlation to evaluate the item's validity. The critical value for 30 samples was 0.361 . Table 1 showed that the statements met the criteria of the validity. Table 1 also indicated that each forces had been consistently measured by our questionnairaes with value no less than 0.7. Thus, our questionnaires should be fine to be deployed into data collecting proccess.

\subsection{Data analysis method}

Our study was categorized as a mapping study which focused to evaluate the current situation of Porter's Five Forces in SMEs industrial forces. We evaluate each forces by using average value on each classified SMEs. Group analysis were employed for our mapping study. 


\section{Result And Discussion}

\subsection{SMEs' Characteristics}

We studied the characteristics of SMEs participated in this study to evaluate the general description or characteristics of the our respondents, namely the SMEs business unit in Medan. The characteristics of the respondents in this study were based on the their group, the gender of owenr, the highest education attainment, and their view of the five-forces. We summarized the respondents' characteristics in Table 2.

Table 2. SMEs Characteristics

\begin{tabular}{ccr}
\hline & N & PERCENTAGE \\
\hline SMES CLASSIFICATION & $\mathbf{3 0 0}$ & \\
\hline Micro Enterprises & 242 & $80,67 \%$ \\
\hline Small Enterprises & 47 & $15,67 \%$ \\
\hline Medium Enterprises & 11 & $3,67 \%$ \\
\hline SEX & $\mathbf{3 0 0}$ & \\
\hline Male & 219 & $73,00 \%$ \\
\hline Female & 91 & $30,33 \%$ \\
\hline EDUCATIONAL ATTAINMENT & $\mathbf{3 0 0}$ & \\
\hline Post-graduate & 21 & $7,00 \%$ \\
\hline Undergraduate & 35 & $11,67 \%$ \\
\hline High School & 198 & $66,00 \%$ \\
\hline Junior High School & 32 & $10,67 \%$ \\
\hline Elementary School & 10 & $3,33 \%$ \\
\hline No School & 4 & $1,33 \%$ \\
\hline FIVE FORCES KNOWLEDGE & $\mathbf{3 0 0}$ & \\
\hline None & 256 & $85,33 \%$ \\
\hline Familiar & 44 & $14,67 \%$ \\
\hline
\end{tabular}

Table 2 provides a general characteristics of SMEs in Medan which were participated in this study. In general, the majority of respondents ware micro businesses. The manager or owner of the business units were generally male. The highest level of educational attainment were high school, and most of the respondents did not know the concept of Porter's Five Forces, let alone applied it in the business

\subsection{Five Forces in SMEs}

This study involved three hundred business units (MSMEs) in Medan based on six categories of featured SMEs. We classified it as Batik, Leather, Rattan, Food, Embroidery, and Souvenirs. Each SMEs group were represented by fifty business units. A structured interviews ware carried out. The mapping results are summarized in Table 3.

Table 3: Porter's Five Forces of SMEs in Medan

\begin{tabular}{lccccccc}
\hline & \multicolumn{7}{c}{ Score } \\
\cline { 2 - 8 } & Medan & Batik & Leather & Rattan & Food & Embroidery & Souveniers \\
\hline Participants & 300 & 50 & 50 & 50 & 50 & 50 & 50 \\
\hline Forces & & & & & & & \\
\hline Suppliers & 3.80 & 4.14 & 4.01 & 4.02 & 4.15 & 3.50 & 3.00 \\
\hline
\end{tabular}




\begin{tabular}{llllllll}
\hline Buyers & 3.65 & 3.49 & 2.85 & 3.67 & 4.35 & 4.13 & 3.41 \\
\hline Rivalry & 3.38 & 3.21 & 3.07 & 3.61 & 3.93 & 3.50 & 2.96 \\
\hline Substitutes & 2.99 & 3.40 & 3.32 & 2.86 & 3.17 & 2.52 & 2.67 \\
\hline New-entry & 3.52 & 3.48 & 3.15 & 3.07 & 4.54 & 3.41 & 3.47 \\
\hline
\end{tabular}

In general, Table 3 provided information in which SMEs in Medan actually had applied force analysis in their business competition through the five forces method, mostly unconciously. However, their implementation of the business management such as the analysis they carried out did not have an impact on their formulation of strategies or the next strategic moves that would be applied by the managers to improve their competitiveness. The study resulted that in general, SMEs in Medan paid enough attention to their strengths and relationships with suppliers, customers, and new entrants to the business. However, they paid less attention to problems related to business competition, rivalry and substitute goods. The analysis conducted by managers took as in daily basis. The next moves taken based on the results of the analysis are also generally spontaneous, there is no planning exercised while managing business competition.

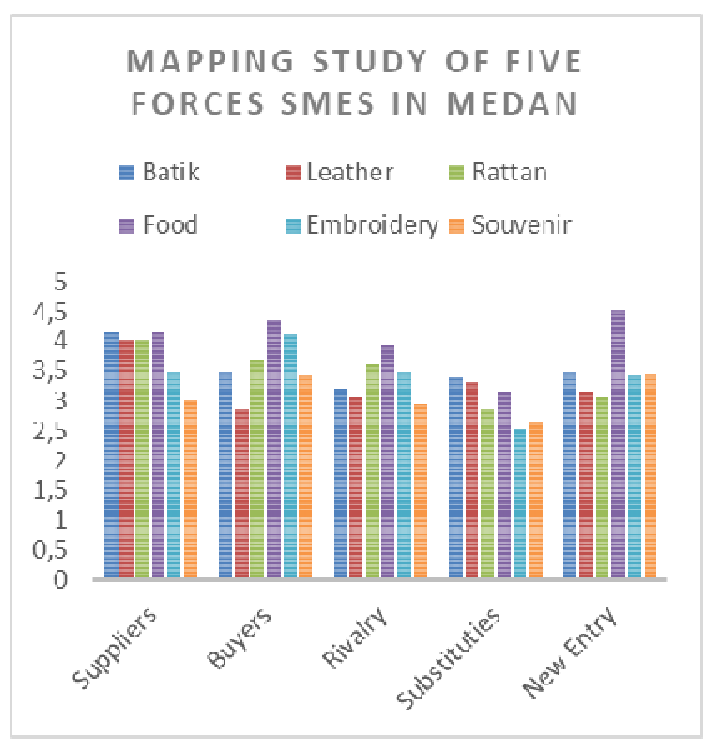

Fig.1. Mapping Study

Figure 1 indicated that the our mapping for each aspect of Porter's Five Forces in each business sector in Medan were quite varaitive. Some business sectors focused more on certain aspects of strength in one of the five forces. For example, the food sector were more focused on the strength of prospective newcomers compared to other sectors. The embroidery sector focused more on aspects of the bargaining power of the buyer. The souvenir sector did not pay enough attention to aspects such as supplier strength, rivalry, and substitute goods. Embroidery was also not paying attention to the power of substitute goods. The Batik sector was quite concerned with many aspects but did not pay attention to the problem of rivalry.

Mapping studies carried out in general provide the similar answers related to the formulation strategies based on the results of the analysis prepared by owners. The five 
forces analysis was not carried out consiously thus the benefits of the analysis were less in aspect to build competitiveness. It was rare sight for the owners to formulate a longterm strategies based on their five forces analysis. For example, the owners had been thinking about how their relationship with suppliers has recently faced problems. The next step that was prepared by the owner was to solve the problem that was experienced at the time, not to lead to competitive advantage in the long term.

\subsubsection{Analysis of Suppliers Power}

Overall, the strength of suppliers from the SMEs business units in Medan had been identified by the owners. They realized the importance of the supply of materials to ensure the flow of their products and develop a higher level of quality. The average value of supplier forces in this mapping study was 3.80 which classified as good. These results indicated that generally the strength of the supplier had been identified by the owners. They had a comprehensive picture of the supply chain of the products offered.

Analysis based on the business sector indicates that awareness of the importance of supplier power to improve business competitiveness was almost in good category, all sectors, except the souvenir sector. In-depth interviews with the owners identified that many of these souvenir businesses are seasonal so that there was no flow of regular supply materials. Generally they did not focus on the quality of raw materials. They could operate by utilizing any raw materials which were available.

\subsubsection{Analysis of Buyers Power}

In general, the bargaining power of buyers from SMEs in Medan had been well identified by the business onwer. The problem in the analysis of force of buyers lied in the leather-based processing sector, such as shoes, bags, belts, and so on. Interviews with the owners indicated that the main problem of controling the forces were based on customer satisfaction and loyalty, which was not a major concern of owners in these sector. It caused a lack of awareness of businesses analysis in the aspect of customer satisfaction and loyalty. In fact, satisfied and loyal customers could be a new source of income for business.

\subsubsection{Analysis of Rivalry}

The strength of business competition, rivalry in industry, was less observed by SMEs in Medan. The sectors that were classified to analyse their rivalry were the food and embroidery sectors. In both sectors, the owners and employees felt that the analysis of customers behavior that was essentially consumptive would encourage more business competition. Therefore, they focused on building healthy business competition and identifying current business competition positions. Other sectors paid less attention to business competition and rivalry issues. They rarely even accurately identify whose were classified as their competitors.

\subsubsection{Analysis of Substitute Goods}

The forces analysis based on substitute goods in general had not been applied by SMEs in Medan yet for every sectors.. The mapping indicated that the embroidery sector was the sector that rarely payid attention to the existence force of substitute goods. Many SMEs in this sectors did not pay attention to the potential of substitute goods, even though the presence of substitute goods was classified as a direct threat to the sustainability of the products offered by these SMEs. The embroidery industry 
argued that the product was unique so that there were no substitute items that should be considered in the industries.

\subsubsection{Analysis of New Entry}

Analysis of new entry in general had been applied quite well by our SMEs, especially in the food sector. They believed that the huge market potential and highly consumptive consumer behavior would bring many new entrant to the market. In addition, a low barrier to entry was one of the focuses problem while anticipating the strength of new entrant to the market. However, the case with the rattan business sector showed a different measurement, many of them did not pay much attention to the force of new entry. They argued that a high barrier were existed in rattan industry. A special skills were required to enter the business so that they did not pay too much attention to the issue of newcomers.

\section{Conclusions}

In essence, many SMEs in Medan were not fully aware of the existence and the benefit of Five Forces Analysis Model. Even though they were unaware to the five forces analysis, they quite oftenly relied on the analysis itself. The analysis conducted by business owner had provided conclusion that there were no feedback to formulation of strategies in the long term to achieve competitive advantage yet. The strategy that was commonly applied was move to overcome the problem of business people at this time. Each business sector had a focus on analyzing the strength of business competition that varies according to their perception of the business environment itself.

Business actors must be able to get used to seeing further from business competition in order to build better business competitiveness than ever. Because most of SMEs were not familiar with the Five Forces analysis, the role of academics is needed to overcome the gap and build the attitude to be able to effectively utilize the Five Forces analysis to improve competitiveness in the future.

\section{Acknowledgments}

The authors gratefully acknowledge that the present research is supported by Ministry of Research and Higher Education. The support is under the research grant PDUPT for year 2018.

\section{References}

[1] Alkhafaji, A. (2003). Strategic management. Formulation, implementation, and control in a dynamic environment. New York: The Haworth Press, Inc.

[2] Anggadwita, G., Mustafid, Q.Y. (2014). Identification of factors influencing the performance of small medium enterprises (SMEs) in Procedia - Social and Behavioral Sciences 115 (IICIES 2013/Elsevier) pp 415-523

[3] Aosa, P. (2009). The Five Forces in the Kenyan Environment. Nairobi: Nairobi University

[4] Asian Productivity Organization. (2015). Handbook for SME Productivity Measurement and Analysis for NPOs. Tokyo: Asian Productivity Organization

[5] Badan Pusat Statistik. (2015). Industri Mikro dan Kecil, accessed from bps.go.id 
[6] Dalken, F. (2014). “Are Porter's Five Competitive Forces still Applicable? A Critical Examination concerning the Relevance for Today's Business", 3rd IBA Bachelor Thesis Conference, University of Twente

[7] Dess, G. G., Lumpkin, G. T. and Eisher, A. B (2006). Strategic Management. Text and cases. International edition. London: McGraw-Hill.

[8] Hill, C. W. L and Jones, G. R. (2007). Strategic Management Theory: An integrated approach. Seventh edition. New York: Houghton Mifflin Company.

[9] Indiasty, C.M., Mwangi, M.S., Mandere, E.N., Bichanga, H.M., George G.E. (2014) The Application of Porter's Five Forces Model on Organization Performance: A Case of Cooperative Bank of Kenya Ltd. European Journal of Business and Management, 6(16), 75-85

[10] Jamil, C.M., Muhamed, R. (2011). Performance measurement system in small medium enterprises: a practical modified framework. World Journal of Social Sciences, 1(3), pp 200-212

[11] Jaradat, S., Almomani, S., Bataineh, M. (2013). "The Impact of Porter Model's Five Competence Powers on Selecting Business Strategy", Interdiciplinary Journal of Contemporary Research in Business 5 (3): 457-14

[12] Karagiannopoulos, G. D., Georgopoulos, N.,and Nikolopoulos, K (2005) 'Fathoming Porter's five forces model in the internet era'. Info Journal. Vol.7 No.6 (2005), pp.66-76. Emerald Group Publishing Limited

[13] Lahiri, S. (2007). Industry-Level Competitive Forces, Firm Resource, Strategy, and Performance: An Investigation of Indian Business Process Outsourcing Providers. Dissertation, the University of Memphis.

[14] Lawrence, Robert Z. 1993. "Competitiveness," The Concise Encyclopedia of Economics. Library of Economics and Liberty. [Online] http://www.econlib.org/library/Enc1/Competitiveness.htm

[15] Lubis, A.N., Lumbanraja, P., Hasibuan, B.K. (2018). Stimulating SMEs performance based on Marketing Mix Approach: A Study of Featured SMEs in Medan, Paper Presented in ICOSTEERR 2018, Medan, Universitas Sumatera Utara

[16] Monbiot, G. (2011). Strategic Management Today. Botwsana: UBRISA

[17] Okoreh, C. O. (2010). The Relevance of Porter's Five Forces Model to the Kenyan Mobile Telephony Industry: A Case of Safaricom Kenya Ltd. Nairobi: Kolbe.

[18] Porter, M. E. (1985). Competitive Advantage: Creating and Sustaining Superior Performance, New York: Free Press

[19] Porter, Michael E. 2008. "The Five Competitive Forces that Shape Strategy", Harvard Business Review, January 2008

[20] Presiden Republik Indonesia. 2008. Undang-Undang No 20 Tahun 2008 tentang Usaha Mikro, Kecil, dan Menengah. Jakarta: Menteri Hukum dan Hak Asasi Manusia Republik Indonesia

[21] Riley, J. (2012). Porter's Five Forces Model: analysing industry structure. [Online] http://www.tutor2u.net/business/strategy/porter_five forces.htm.

[22] World Bank. (2018). Global Economic Prospects 2018: Trade, Regionalism, and Development

[23] World Economic Forum. (2016). Global Competitiveness Report 2013-2015. [Online] http://reports.weforum.org/ 